\title{
Teachers' Perception towards Online Science Learning during the Pandemic
}

\author{
Sajidan', Fadhil Purnama Adi $^{2}$, Idam Ragil Widianto Atmojo3, Roy \\ Ardiansyah4, Moh Salimi 5, Adelia Anisa6
}

DOI: 10.35445/alishlah.v13i1. 521

Info Artikel

Keywords:

Teacher's Perception

Online Science Learning

Science Process Skills
Kata kunci:

Persepsiguru

Pembelajaran daring

Keterampilan Proses

Sains

\section{Abstract}

This study aims to describe the perceptions of SD Angkasa Colomadu teachers on online science learning during the pandemic. This research used descriptive qualitative research methods and a case study approach. The subjects of this study were three teachers of grades IV, V, and VI SD Angkasa Colomadu in the academic year 2020/2021. Data collection techniques used interviews and documentation. The data validity test techniques used the triangulation technique. Data analysis techniques used interactive analysis techniques Miles and Huberman consisting of data reduction, data display, and conclusions. The results show that the teachers felt that learning sciences in the network was not optimal. Teachers do not optimally apply basic process skills. The teachers feel the limitation in the communication process. They also have a restriction on directing the students to formulate hypotheses, conclude the material, guide experimental activities, attract students to ask questions, guide the measurement process, guide observation activities, classify, interpret, and predict processes due to media limitations. On the other hand, teachers feel that online learning makes teachers more innovative, creative, and able to take advantage of cellphones, computers, and the internet in learning activities, especially in learning science online during the pandemic period.

\begin{abstract}
Abstrak
Penelitian ini bertujuan untuk mendeskripsikan persepsi guru SD Angkasa Colomadu terhadap pembelajaran IPA dalam jaringan selama masa pandemi. Penelitian ini merupakan penelitian kualitatif dengan metode penelitian kualitatif deskriptif dan pendekatan studi kasus. Subjek penelitian ini adalah guru kelas IV, V, dan VI SD Angkasa Colomadu tahun ajaran 2020/2021 yang berjumlah 3 orang. Teknik pengumpulan data menggunakan wawancara dan dokumentasi. Teknik uji validitas data menggunakan teknik triangulasi. Teknik analisis data menggunakan teknik analisis interaktif Miles dan Huberman yang terdiri dari reduksi data, penyajian data, dan penarikan simpulan. Hasil
\end{abstract}

\footnotetext{
${ }^{1}$ Universitas Sebelas Maret, Indonesia Email: sajidan fkip@uns.ac.id 2 Universitas Sebelas Maret, Indonesia Email: fadhil@staff.uns.ac.id

3 Universitas Sebelas Maret, Indonesia Email: idamragil@fkip.uns.ac.id

4 Universitas Sebelas Maret, Indonesia Email: royardiansyah@staff.uns.ac.id

5 Universitas Sebelas Maret, Indonesia

Email: salimi@staff.uns.ac.id

5 Universitas Sebelas Maret, Indonesia

Email: adeliaanisa@student.uns.ac.id
} 
penelitian menunjukkan bahwa guru merasa pembelajaran IPA dalam jaringan tidak maksimal. Guru tidak maksimal menerapkan keterampilan proses sains dasar. Guru merasa terbatas dalam proses mengkomunikasikan, mengarahkan peserta didik menyusun hipotesis, mengarahkan peserta didik menyimpulkan materi, membimbing kegiatan percobaan, menarik peserta didik untuk bertanya, membimbing proses pengukuran, membimbing kegiatan observasi, proses menggolongkan, menafsirkan, dan meramalkan karena keterbatasan media. Guru merasa pembelajaran dalam jaringan (daring) membuat guru menjadi lebih inovatif, kreatif dan mampu memanfaatkan penggunaan hp, komputer, internet dalam kegiatan pembelajaran, terutama dalam pembelajaran IPA dalam jaringan (daring) selama masa pandemi.

\section{INTRODUCTION}

The Covid-19 pandemic has influenced all the aspect of life, including education. The government has already implemented a study from home policy in the education field that stated on Surat Edaran Nomor 4 the Year 2020 about implementing the educational policy during the emergency of outbreak COVID-19. Education conducted during the Covid-19 pandemic is longdistance learning that is called online learning. Online learning enables someone to access certain content through technology without time and distance limitation and physical touch between the teachers and the students (Ramadhan et al., 2018).

During the pandemic, the elementary school level also implements online learning. It changes the learning pattern from direct (face to face) learning becomes online (Putria et al., 2020). Based on the survey, about $82.6 \%$ of teachers feel that they are helped to deliver the material during the pandemic, yet the effectiveness is still low (Fauzi \& Sastra Khusuma, 2020). This ineffectiveness is influenced by the obstacles found during online learning, such as the lack of preparedness of the teachers in using the technology, unstable internet connection, the difficulties in maintaining the online learning, the challenges in conducting the research, and the limitation to observe the students (Rigianti, 2020).

The implementation of online learning cannot be separated from the life challenges which require the students to have 21st-century skills. Those skills are communication, collaboration, critical thinking and problem solving, and creativity and innovation prepared for science learning (Pratiwi et al., 2019). Science learning is memorizing and collecting facts, concepts, and principles and requires the students' participation in finding the process and giving real experiences (Astuti, 2019). This becomes one of the challenges to conduct online science learning, especially at the elementary school level, with the students' characteristics who have not thought abstract things (Bujuri, 2018).

Science learning has characteristics where the students are required to memorize the materials and master the facts, concepts, or principles. The students have to be involved during the finding (Astuti, 2019). The characteristics of science learning become the challenge during online science learning, especially at the elementary school level where the students on the concrete operational stage. When the students can think logically on the concrete things, they haven't been able to think about abstract things (Bujuri, 2018).

Science learning in elementary school is a compulsory subject to be learned by the students. The science materials in elementary school contain natural knowledge close to their daily lives (Sobron et al., 2019). Science learning in elementary school is expected to introduce and understand students about natural knowledge and solve science problems in daily life.

The implementation of online science learning creates some perceptions. Perception is an understanding of a situation in the form of stimulus gained through senses, forwarded to the brain to be selected, and organized to create an interpretation in the form of assessment reflected in the behaviour (Irawan, 2018; Maharani et al., 2017). Teachers' perception is crucial because teachers have essential roles in education (Huizenga et al., 2017). Teachers' perception of teaching-learning influences how they see the students' ability and teaching methods to be implemented (Okon \& Anya, 
2020). Teachers' perception is important because it will influence the teachers' acts. One of them is the preference to use modern technology during the teaching process (Qasem \& Nathappa, 2016).

The research is done by Auma \& Achieng (2020) shows that teachers have a positive perception of online learning. Yet, some factors hinder the implementation of online learning, such as the lack of IT infrastructure, the lack of the teachers' ability to online learning, and the lack of training for implementing IT. Research is done by Fauzi \& Khusuma (2020), Rizal et. al. (2020) show that the teachers agree to conduct online learning during the pandemic since the condition does not allow them to conduct conventional (face to face) learning. The result shows that the teachers understand online learning, but they found some problems during the implementation. However, there has not been any research discussed the teachers' perception towards science learning in elementary school. Research about perception in science learning becomes one of the important things.

Research about perception in science learning becomes one of the essential things. The teachers' perception will influence in conducting the teaching-learning process. The teachers' perception is needed to create a policy that encourages the students to perform a good teaching-learning process. Therefore, this research aims to describe the teachers' perception of online science learning during the pandemic.

\section{METHOD}

The methodology used in this research is a descriptive qualitative methodology with a case study approach. This research approach investigates a particular case intensively, in detail, depth, and comprehensively based on the facts (Lubis et al., 2019). This research was conducted at SD Angkasa Colomadu. This place of the research was chosen based on some considerations: (1) SD Angkasa Colomadu is one of the elementary schools in Surakarta Regency which conducts online learning during the pandemic. (b) SD Angkasa Colomadu has not been used yet as the research object with variable and research subject from the researcher. The subjects in this research were three teachers of grades IV, V, and VI SD Angkasa Colomadu. This research used purposive sampling to determine the subjects of the research. Purposive sampling is a technique for obtaining a sample based on the researcher's purpose (Sukmadinata, 2013). The researcher chose the research subjects considering that science learning at the IV, V, and VI grades can be independent, as stated in Permendikbud no. 37 the year 2008. The data in this research were gathered through semi-structured interviews. A semi-structured interview was chosen because it can be developed to deepen the information. Documents being analyzed were videos, photos, and documents related to online science learning at SD Angkasa Colomadu.

The data validity test technique used the triangulation technique. This technique checks the data from many resources in multiple ways and times (Sugiyono, 2015). In this research, the researcher validates the teachers' data to interview and documentation to acknowledge the teachers' perception towards online science learning.

Data analysis techniques used interactive analysis techniques Miles and Huberman, consisting of data reduction, data display, and conclusions (Sugiyono, 2015). Data reduction is a technique to sharpen the data, categorize, adjust the data, and sort the data needed with certain techniques to draw a conclusion (Jana, 2018; Rijali, 2019). The process of data sorting was conducted strictly following the research purpose. The researcher summarizes the data into a concept and certain categories. Data display creates a research report for the data can be understood and analyzed following the research purpose. Data display was done systematically, which allow drawing conclusion and action. After data display, the researcher concludes. The conclusions were supported by pieces of evidence obtained in the field. The conclusion drawn is in line with the research problems and research purpose. The researcher can draw a conclusion about the teachers' perception towards online science learning by comparing the ideal science learning conditions. 


\section{RESEARCH FINDINGS AND DISCUSSION}

Science learning at SD Angkasa Colomadu is held through WhatApp as the primary learning platform. The teachers utilize group chat, private chat, and video call to communicate with the students or the parents. The teachers give the instructions through the WhatsApp group and explain the particular task. Here is some documentation of activities of online science learning at SD Angkasa Colomadu.

Teachers have a perception towards online science learning when (1) the teachers directly involve in online science learning, (2) the teachers compare online science learning with conventional science learning, (3) the teachers convey their thought about online science learning, (4) the teachers give responses in the form of action towards online science learning (Irawan, 2018; Maharani et al., 2017; Soraya, 2018). Based on the documentation from the research subjects, it is known:

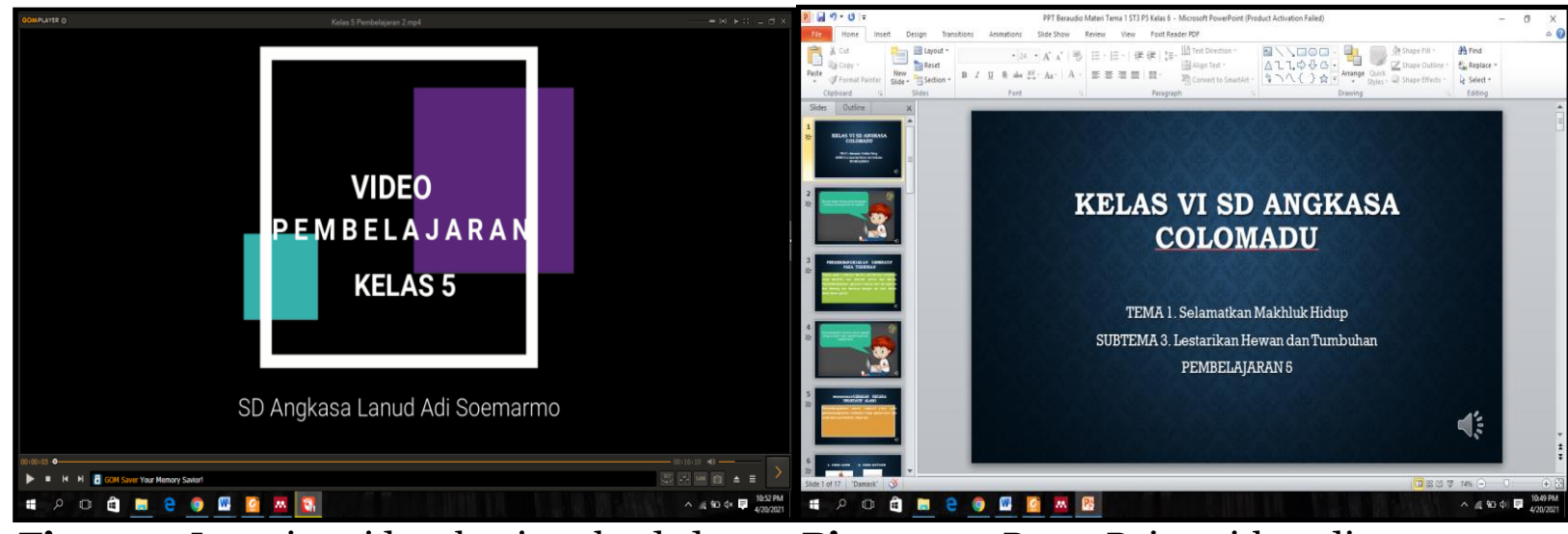

Figure 1. Learning video that is uploaded Picture 2. PowerPoint with audio to YouTube

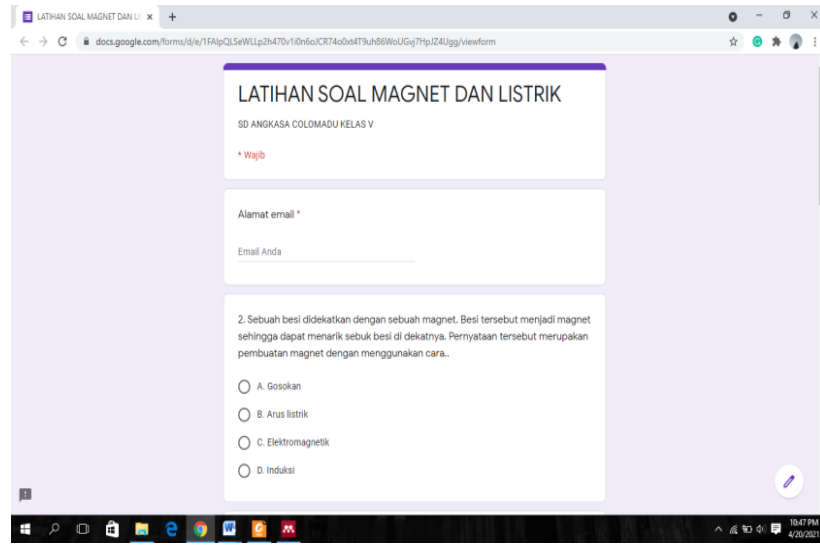

Figure 3. Online exercise on the google form

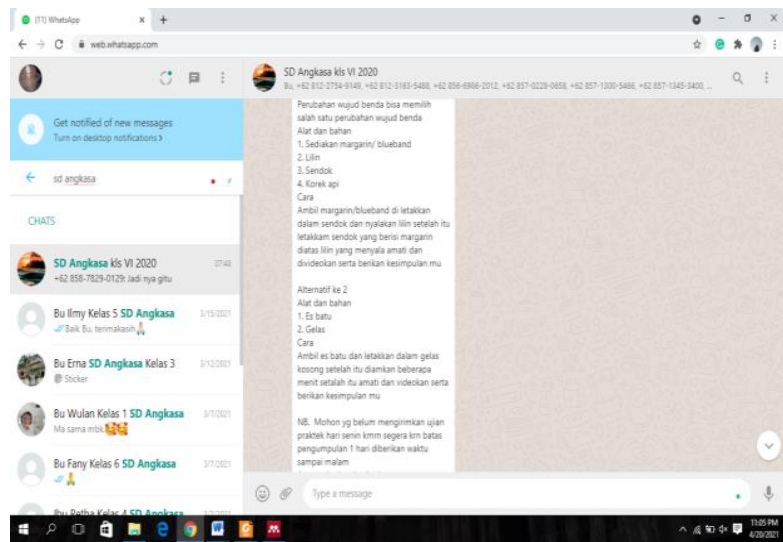

Figure 4. Captured of Science online learning

The teachers gave a simple experiment task to the students. The experiment was conducted individually at home or around the home with the parent's guidance. The teachers gave explanations about the tools, materials, and experiment steps through Whatsapp. The result of the experiments was submitted in the form of a short description, documentation during the experiment in the form of photos and videos, and question and answer sessions when doing a video call.

\section{The Teachers Directly Involved in Online Science Learning}

Below are the interview results with the teachers about their involvement during online science learning. 
"for explaining material in online science, learning is quite limited. The material taught to the students depends on the textbook and students' worksheets (LKS), then we give videos from YouTube. The teaching-learning via WhatsApp, in my opinion, is already going well even though it has not been maximal yet due to some lacks, face to face learning is more effective." (WAN/GRIV/MGT/1O/o3/2021)

"During online learning, I could not explain the material in detail since I cannot meet the students face to face, and we cannot have to-ways communication due to the limitation of media (communication)." (WAN/GRV/ILM/10/o3/2021)

"In my opinion (online learning) is not effective. In offline learning, we can deliver the materials directly, while in online learning we cannot. We only send the materials using videos or PPT with audio. From the parents' side, it is difficult to have a Zoom meeting."(WAN/GRVI/FNY/10/o3/2021)

Based on the interview statements, the teachers communicated the science materials through Whatsapp by giving materials from the textbook, LKS (student worksheet), PowerPoint with audio, and sending the learning videos. The teachers choose Whatsapp because it is considered the most effective to conduct online learning at SD Angkasa Colomadu. As stated by (Yanto et al., 2021), the teachers' platform influences elementary students' participation in online learning. The communication between the teachers and the students is limited because some students have not got any personal cellphones. The teachers could not convey the material in detail. The teachers direct the students in developing the hypothesis in online science learning by giving explanations and examples. The teachers direct the students to conclude the materials, yet it was not maximal because the discussion in online learning has not been done well. As stated by (Kumala, 2016), science learning in elementary school implements basic science skills. The communication process and conclusion are the basic science skills as stated by (Suryaningsih, 2017). The communication process, which is not maximal, directs the students to build hypotheses and directs the students to conclude that the discursive aspect is not maximal yet. As stated by (Oktavian \& Aldya, 2020), ideal online learning enables a discussion process. Meanwhile, the teachers' teaching-learning activities influence the students' basic science skill (Mufidah et al., 2019).

\section{The Teachers Compare Online Science Learning with Offline Science Learning}

The interview results the teachers compare the online science learning with offline science learning:

"Usually during offline learning, I can accompany the students to hold an experiment, while it depends on their parents during online learning. Some parents cannot accompany their children because they have to work, and some students do not have their smartphones. In my opinion, the s4th grade students need assistance, and they also need to wait for their parents if they want to do the assignments." (WAN/GRIV/MGT/1O/O3/2021)

"During offline learning, students usually were accompanied by the teachers when they do experiments, but they need the parents' guidance when conducted at home. Meanwhile, some parents do not understand science materials and some others cannot accompany their children. In my opinion (online learning) is not maximal, even we know that the students are expected to be independent." (WAN/GRV/ILM/10/o3/2021)

"When we conduct offline learning, the experiments usually were conducted in groups, while online learning is conducted individually. It makes the students less enthusiastic. They cannot work together and share their ideas with their friend. 
Moreover, the experimental tools at home are not as complete as at school." (WAN/GRVI/FNY/10/o3/2021)

The teachers compare that the experiments in online science learning take a longer duration than online learning. The teachers cannot directly accompany the students; therefore, the parents need to accompany them. It makes the students less enthusiastic. They are not cooperative and cannot share their opinions with their friends during the individual experiments. The students become less active in conveying the questions in online science learning. The measurement process in online learning is not maximum because the teachers cannot guide the students directly and limit experimental tools. The teachers also compare the observation process during online science learning, which is considered not maximum. It is held at home where the teachers cannot observe them directly. As stated by (Sulthon, 2017), science learning should develop cooperation that the science learning should create teamwork and sharing opinion to solve science problems. It also needs the students' participation in the finding process (Mahpudin, 2018). The learning gives chances to the students to solve the science problems in daily life (Tias, 2017).

\section{The Teachers Convey Their Thought about Online Science Learning}

Interview results with the teachers about their thought of online science learning:

"In my opinion, the students' ability to classify is not maximal. To make students have the ability to classify, guidance, watching some examples from videos are needed." (WAN/GRIV/MGT/1O/O3/2021)

"In my opinion, during online learning, the students cannot classify with maximal. The students need some examples from videos on how to classify something and exercises. (WAN/GRV/ILM/1O/O3/2021)

"The students' ability to interpret is not understood because they are expected to solve problems independently without guidance and the parents' limitation about (science) knowledge”. (WAN/GRVI/FNY/1O/o3/2021)

"In my opinion, the activity to predict during online learning depends on the students' parents. Some can do it, but some others have not been maximal yet because the parents have different knowledge, and their parents are not accompanying some students." (WAN/GRVI/FNY/1O/o3/2O21)

The teachers convey their thought about online learning. The teachers' opinion about the classifying process has not been maximal yet. The teachers believe that the students' ability to interpret the materials in online learning is already good. However, on some materials, the students need some guidance. Based on the teachers' opinion, the students' ability to predict a certain thing is not maximal yet because they need the teachers' advice directly, and they also need examples. This shows that the teachers convey their thought about the implementation of online science learning. This is in line with (Soraya, 2018) about the perception that an individual will respond to information in form of opinions, responses, or actions have shown.

\section{The Teachers Give the Response in the Form of Action towards Online Science Learning}

Interview results with teachers about the responses given in the form of action towards online science learning

"The teaching preparation is easier during offline learning. Online learning takes more time and preparation. However, when I make learning videos, I feel more innovative when I make learning videos even though it consumes time to take and edit the videos. It is better to deliver the material one day before so the students can study it at first." WAN/GRIV/MGT/1O/O3/2021) 
"The preparation for online science learning has required the teachers to be extracreative and innovative, such as making learning videos and other teaching media. We cannot deny that it is more complicated. It is better to deliver the material one day before the lesson." (WAN/GRV/ILM/10/O3/2021)

"I spare more time to prepare the learning. It needs much time because I have to make videos or PPT. However, it makes the teachers more creative." (WAN/GRVI/FNY/1O/O3/2O21)

The teachers become more innovative and creative by making interactive learning videos and PowerPoint with audio even though it takes extra preparation. The use of interactive teaching media is expected to improve the students learning outcomes during online science learning. This is in line with (Hadijah et al., 2020) research that interactive teaching media is effective to help the students study. The teachers' teaching media and teaching methods influence the quality of science teaching (Rosyada et al., 2021).

The assessment is conducted through the questions made by the teachers on the google form. Some students' work must be checked by the teachers one by one via smartphones, it is considered tiring by the teachers. The assessment process is not satisfactory yet for the teachers even though some score improvements because they believe the parents or the internet helps some students.

The action shown by the teachers towards the implementation of online science learning is that the teachers try to be professional and give the best and build an exciting environment. This is in line with (Helmi, 2015) that an experienced teacher always gives the best in the teaching-learning process. The teachers give the government advice to give the supported facilities in conducting the online science learning. The teachers also advise the parents to accompany the students at home and prioritise the mid of the parents' schedules. The teachers hope that conventional (face-to-face) learning can be held soon. As stated by (Hernanto et al., 2021), parents influence students' motivation and students' learning outcomes during online learning.

The teachers' actions and behaviour are responses towards online science learning. These influence the teaching-learning process (Susanti, 2019). The teachers' preparation takes a longer duration, more innovative, and creative to give meaningful learning. This is in line with the implementation of online learning by (M.D. Miller, 2020), who stated that online learning still van present meaningful learning for the students.

\section{CONCLUSION}

This research concludes that the teachers' perception of SD Angkasa Colomadu towards online science learning from implementing basic science skills and science learning components during online learning is not maximal yet. The teachers feel they cannot communicate optimally because it is limited when they deliver the material virtually. The teachers find it difficult to guide the students when the students are doing experiments, encourage them to ask during the teaching-learning actively, guide the measurement process, and guide the observation because of the limitation of the distance and interaction media the teachers and the teachers students. The classifying process, interpretation, and prediction during online science learning can be made even though it has not been maximal yet because the students spend most of their time at home with their parents. However, the teachers feel that online learning makes the teachers more innovative, creative, and able to use smartphones, computers, and the internet to conduct teaching-learning processes especially online science learning during the pandemic.

\section{REFERENCE}

Astuti, T. P. (2019). Model Problem Based Learning dengan Mind Mapping dalam Pembelajaran IPA Abad 21. Proceeding of Biology Education, 3(1), 64-73.

Auma, O. M., \& Achieng, J. (2020). Perception of Teachers on Effectiveness of Online Learning in the wake of COVID-19 pandemic. IOSR Journal Of Humanities And Social Science (IOSR-JHSS, 
25(6), 19-28. https://doi.org/10.9790/o837-2506111928

Bujuri, D. A. (2018). Analisis Perkembangan Kognitif Anak Usia Dasar dan Implikasinya dalam Kegiatan Belajar Mengajar. LITERASI (Jurnal Ilmu Pendidikan), 9(1), 37. https://doi.org/10.21927/literasi.2018.9(1).37-50

Fauzi, I., \& Sastra Khusuma, I. H. (2020). Teachers' Elementary School in Online Learning of COVID19 Pandemic Conditions. Jurnal Iqra': Kajian Ilmu Pendidikan, 5(1), 58-70. https://doi.org/10.25217/ji.v5i1.914

Hadijah, S., Marhamah, M., \& Shalawati, S. (2020). Interactive and Educative Learning Media in English Language Teaching At Senior High Schools. AL-ISHLAH: Jurnal Pendidikan, 12(2), 304-315. https://doi.org/10.35445/alishlah.v12i2.202

Helmi, J. (2015). Kompetensi Profesionalisme Guru. Jurnal Pendidikan, 7(2), 319-336. http://journal.staihubbulwathan.id/index.php/alishlah/article/view/43/38

Hernanto, M. D., Atmojo, I. R. W., \& Ardiansyah, R. (2021). Persepsi orang tua peserta didik kelas IV SD terhadap platform pembelajaran dalam jaringan ( daring ) IPA selama masa sindemi. Jurnal Pendidikan Indonesia UNS, 34-39.

Huizenga, J. C., ten Dam, G. T. M., Voogt, J. M., \& Admiraal, W. F. (2017). Teacher perceptions of the value of game-based learning in secondary education. Computers and Education, 110, 105-115. https://doi.org/10.1016/j.compedu.2017.03.008

Irawan, V. W. E. (2018). Urgensi Persepsi Peserta Didik dalam Menilai Kompetensi Dosen. Jurnal Ilmiah Ilmu Sosial Dan Keagamaan, o7(1), 148-158.

Jana, P. (2018). Analisis Kesalahan Mahasiswa Dalam Menyelesaikan Soal Matematika Pada Pokok Bahasan Vektor. Jurnal Mercumatika : Jurnal Penelitian Matematika Dan Pendidikan Matematika, 2(2), 8. https://doi.org/10.26486/jm.v2i2.398

Kumala, F. N. (2016). Pembelajaran IPA Sekolah Dasar. In Ediide Infografika (Vol. 8, Issue 9).

Lubis, R. R., Haidir, \& Rusadi, B. E. (2019). Problematika Implementasi Scientific Approach dalam Pembelajaran Fikih (Studi Kasus Di MTs. PAI Medan). Jurnal Agama Dan Pendidikan Islam, 11(1), 118-134.

M.D. Miller. (2020). Going online in a hurry: What to do and where to start. Chronicle, Vol 5(Nomor 2), 8-10.

Maharani, R., Nuarini, F., \& Andrianto. (2017). Analisis Perbedaan Persepsi Akademisi Akuntansi terhadap Penerapan Mata Kuliah Akuntansi Syariah. Jurnal Ekonimi Dan Bisnis Islam, 3(1), $39-48$.

Mahpudin. (2018). Peningkatan Hasil Belajar Ipa Melalui Metode Eksperimen Pada Siswa Kelas V Sekolah Dasar. Jurnal Cakrawala Pendas, 4(2), 1. https://doi.org/10.31949/jcp.v4i2.1029

Mufidah, I. A., Badarudin, \& Yuwono, P. H. (2019). the Implementation of Science, Technology, Engineering, and Mathematics (Stem) Learning To Improve Basic Asking Skills and Learning Achievements Students of Elementary School. AL-ISHLAH: Jurnal Pendidikan, 11(2), 210. https://doi.org/10.35445/alishlah.v11i2.133

Okon, M. O., \& Anya, O. P. (2020). Teachers' Self -Perception, Knowledge of Inclusive Education and Classroom Practices among Primary School Teachers in Ogoja Education Zone, Cross River State. Journal Education, 146-158.

Oktavian, R., \& Aldya, R. F. (2020). Efektivitas Pembelajaran Daring Terintegrasi di Era Pendidikan 4.o. Didaktis: Jurnal Pendidikan Dan Ilmu Pengetahuan, 2O(2), 129-135. https://doi.org/10.30651/didaktis.v20i2.4763

Pratiwi, S. N., Cari, C., \& Aminah, N. S. (2019). Pembelajaran IPA Abad 21 dengan Literasi Sains Siswa. Jurnal Materi Dan Pembelajaran Fisika (JMPF), 9, 34-42.

Putria, H., Maula, L. H., \& Uswatun, D. A. (2020). Analisis Proses pembelajaran Dalam Jaringan (DARING) Masa Pandemi COVID-19 pada Guru Sekolah Dasar. Jurnal Basicedu, 4(4), 861-872. https://doi.org/10.31004/basicedu.v4i4.460

Qasem, A. A. A., \& Nathappa, V. (2016). TEACHERS' PERCEPTION TOWARDS ICT INTEGRATION: PROFESSIONAL DEVELOPMENT THROUGH BLENDED LEARNING. Journal Education, 2026.

Ramadhan, R., Chaeruman, U. A., \& Kustandi, C. (2018). Pengembangan Pembelajaran Bauran ( Blended Learning ) di Universitas Negeri Jakarta. Jurnal Pembelajaran Inovatif, 1(1), 37-48. http://journal.unj.ac.id/unj/index.php/jpi/article/view/5935

Rigianti, H. A. (2020). Kendala Pembelajaran Daring Guru Sekolah Dasar Di Kabupaten Banjarnegara. Elementary School, 28(2), 1-43. 
http://journals.sagepub.com/doi/10.1177/1120700020921110\%oAhttps://doi.org/10.1016/j.reu ma.2018.06.001\%oAhttps://doi.org/10.1016/j.arth.2018.03.044\%oAhttps://reader.elsevier.com /reader/sd/pii/S1063458420300078?token=Co39B8B13922A2079230DC9AF11A333E295FCD 8

Rijali, A. (2019). Analisis Data Kualitatif [Qualitative Data Analysis]. Alhadharah: Jurnal Ilmu Dakwah, 17(33), 81.

Rizal, R. M., Sanapiah, \& Kurniawan, A. (2020). Persepsi Guru SDN 4 Teros Terhadap Pembelajaran Daring Di Masa Pandemi COVID-19. JPIn: Jurnal Pendidik ..., 3(2), 36-41. http://jurnal.intancendekia.org/index.php/JPIn/article/view/102

Rosyada, M. I., Atmojo, I. R. W., \& Saputri, D. Y. (2021). Dampak implementasi pembelajaran dalam jaringan ( daring ) mengenai kualitas pembelajaran ipa di sekolah dasar pada masa pandemi covid-19. Jurnal Didaktika Dwija Indria, 9(4), 1-5. https://jurnal.uns.ac.id/JDDI/article/view/49180

Sobron, A. ., Meidawati, S., Bayu, \& Rani. (2019). Persepsi Siswa Dalam Studi Pengaruh Daring Learning Terhadap Minat Belajar Ipa. SCAFFOLDING: Jurnal Pendidikan Islam Dan Multikulturalisme, 1(2), 30-38. https://doi.org/10.37680/scaffolding.v1i2.117

Soraya, N. (2018). Analisis Persepsi Mahasiswa Terhadap Kompetensi Dosen dalam Mengajar Pada Program Studi PAI Fakultas Ilmu Tarbiyah dan Keguruan UIN Raden Fatah Palembang. Jurnal Fakultas Ilmu Tarbiyah Dan Keguruan UIN Raden Fatah Palembang, IV.

Sugiyono. (2015). Metode Penelitian Pendidikan. Alfabeta.

Sukmadinata, N. S. (2013). Metode Penelitian Pendidikan. PT Remaja Rosdakarya.

Sulthon. (2017). Pembelajaran IPA yang Efektif dan Menyenangkan bagi Siswa Madrasah Ibtidaiyah (MI). ELEMENTARY: Islamic Teacher Journal, 4(1). https://doi.org/10.21043/elementary.v4i1.1969

Suryaningsih, Y. (2017). Pembelajaran Berbasis Praktikum Sebagai Sarana Siswa untuk Berlatih Menerapkan Keterampilan Proses Sains dalam Materi Biologi. Bio Educatio, 2(2), 279492.

Susanti, M. M. I. (2019). Perbedaan Persepsi Guru Sekolah Dasar Berdasarkan Lama Mengajar Tentang Kurikulum 2013. Elementary Journal, 1(2), 12-21.

Tias, I. W. U. (2017). Penerapan Model Penemuan Terbimbing Untuk Meningkatkan Hasil Belajar Ipa Siswa Sekolah Dasar. DWIJA CENDEKIA: Jurnal Riset Pedagogik, 1(1), 50-60. https://doi.org/10.20961/jdc.v1i1.1306o

Yanto, N., Wahyuningsih, S., \& Suharno. (2021). Analisis Minat Belajar Peserta Didik Sekolah Dasar di Rumah Sebagai Dampak Pandemi COVID-19. Jurnal Pendidikan Dasar, 52-57. 